\title{
A hazai csecsemőhalandóságban 2019-ben tapasztalt emelkedés lehetséges okainak vizsgálata
}

\author{
Valek Andrea dr. ${ }^{1}$ - Vitrai József dr. $^{2}$ - Erdei Lilla ${ }^{1}$ \\ Branyiczkiné Géczy Gabriella ${ }^{3}$ - Pászthy Bea dr. ${ }^{4}$ \\ Szabó Attila dr. ${ }^{4}$ - Szabó Miklós dr. ${ }^{1}$ \\ ${ }^{1}$ Semmelweis Egyetem, Általános Orvostudományi Kar, I. Gyermekgyógyászati Klinika, \\ Neonatológiai Tanszéki Csoport, Budapest \\ ${ }^{2}$ Nyugdíjas népegészségügyi szakértő \\ ${ }^{3}$ Központi Statisztikai Hivatal, Népszámlálási és népesedési statisztikai főosztály, Budapest \\ ${ }^{4}$ Semmelweis Egyetem, Általános Orvostudományi Kar, I. Gyermekgyógyászati Klinika, Budapest
}

Bevezetés: Magyarországon a csecsemőhalandóság 2014 óta folyamatosan javult, azonban 2019-ben az előző évi adathoz képest 11\%-kal magasabb érték mutatkozott.

Célkitüzés: A vizsgálat célja a 2019. évi kedvezőtlenebb csecsemőhalálozási mutató lehetséges összetevőinek feltárása. Módszer: A 2018. és 2019. évi csecsemőhalálozási adatokat hasonlítottuk össze a csecsemő kora, a halál oka és a gyógyintézeti, illetve nem gyógyintézeti elhalálozás szerint. A vizsgálathoz a Központi Statisztikai Hivatal adatait használtuk. A trendvizsgálatnál 2010-tôl elemeztük az adatokat. A nem gyógyintézeti haláleseteket 10 évre összevonva járásonként térképesen ábrázoltuk.

Eredmények: 2018-ban 304, 2019-ben 335 csecsemő halt meg Magyarországon, a csecsemőhalálozási arányszám 3,4 ezrelékről 3,8 ezrelékre emelkedett. A 2019. évi érték az előző évtizedek trendjére illesztett görbe alapján megfelelt a várható értéknek. 2019-ben a 0-27 napos csecsemőhalálozás alig változott a 2018. évihez képest, a 28-364 napos korban bekövetkezett halálesetek száma viszont növekedett. A vizsgált évben 59\%-kal emelkedett a nem gyógyintézeti csecsemőhalálozás. A 2019. évi csecsemőhalálozás növekedéséért 74\%-ban a nem gyógyintézeti esetek voltak felelősek. A nem gyógyintézeti halálozás döntő többsége késői csecsemőkorban következett be. A járásonkénti, 10 évre összevont, nem intézményben elhunyt csecsemők számában és 1000 élve születésre vonatkozó arányában ötszörös területi különbségek mutatkoztak. A halálokok közül a perinatalis szakban keletkező bizonyos állapotok miatt meghalt csecsemők száma emelkedett a leginkább, a nem gyógyintézeti halálozás esetében pedig a hirtelen csecsemőhalál szindrómában meghaltaké.

Következtetés: 2019-ben kiugróan magas volt a nem gyógyintézeti, késői csecsemőhalálozás száma és részaránya, ezen esetek feltűnő regionális halmozódást mutattak. A csecsemőhalandóság csökkentésének hatásos eszköze lehetne a jövőben minden egyes csecsemőhalál részletes szakmai értékelése.

Orv Hetil. $2021 ; 162(1): 830-838$

Kulcsszavak: csecsemőhalálozás, földrajzi térképezés, halálok, hirtelen csecsemőhalál szindróma

\section{Investigation of possible causes of increase in Hungarian infant mortality in 2019}

Introduction: In Hungary, infant mortality has been steadily declining since 2014, but in 2019 it increased by $11 \%$ compared to 2018 .

Obbjective: The aim of our study is to explore the possible components of the above increase.

Method: Ten-year trends of infant mortality were analized and compared by age, cause, place of deaths (hospital or non-hospital environment) and location, using Central Statistical Office data.

Results: There were 304 infant deaths in Hungary in 2018 and 335 in 2019. Infant mortality rate rose from 3.4\% to $3.8 \%$, however, it was in line with the expected value based on the curve fitted to the trend of previous decades. In $2019,0-27$-day infant mortality basically did not change compared to 2018 , while the number of deaths at 28-364 days of age increased. Non-hospital infant mortality increased by $59 \%$ in 2019 and these cases accounted for $74 \%$ of 
the total increase in infant mortality; the vast majority of these deaths occurred in late infancy. There were fivefold regional differences in the number of non-hospital infant deaths. Among the causes of death, the conditions related to the perinatal period and sudden infant death syndrome increased the most.

Conclusion: In Hungary, the number and proportion of non-hospital infant mortality was remarkably high in 2019 compared to previous years. These cases showed a striking regional accumulation. An effective tool for reducing infant mortality could be an appropriate professional assessment of each infant death in the future.

Keywords: infant mortality, geographic mapping, cause of death, sudden infant death syndrome

Valek A, Vitrai J, Erdei L, Branyiczkiné Géczy G, Pászthy B, Szabó A, Szabó M. [Investigation of possible causes of increase in Hungarian infant mortality in 2019]. Orv Hetil. 2021; 162(21): 830-838.

(Beérkezett: 2020. október 22.; elfogadva: 2021. január 8.)

\section{Rövidítések}

BNO = Betegségek Nemzetközi Osztályozása; KSH = Központi Statisztikai Hivatal; NEAK = Nemzeti Egészségbiztosítási Adatkezelő; SIDS = (sudden infant death syndrome) hirtelen csecsemőhalál szindróma

A halálozási adatokon belül sajátos csoportot képvisel a csecsemóhalálozás, amely - mint a halálozási adatok általában - nem annyira a lakosság egészségi állapotát, mint inkább az adott ország egészségügyi ellátórendszerének fejlettségét, a várandósgondozás, a szülészeti tevékenység és az újszülöttellátás színvonalát tükrözi $[1,2]$. Ezenkívül a csecsemőhalálozás érzékeny mutató egy adott terület társadalmi-gazdasági fejlettségére is $[3,4]$. Bár az összhalálozásban egyre kisebb a részaránya, kulcsszerepe van a születéskor várható átlagos élettartam alakulásában, mivel az egyéves életkor elérése előtti elhalálozás valószínúsége is kiemelkedően magas a későbbi életkorok halálozási kockázataihoz képest [5]. Fontossága és népmozgalmi statisztikákból való könnyú elérhetősége miatt nemzetközi kimutatások alapvető mérőszáma $[6,7]$.

A csecsemőhalandóság javulása egész Európára jellemző, azonban a csökkenés mértéke különböző az egyes országokban $[8,9]$. Magyarországon a csecsemőhalandóság javulásának eredményeként az újszülöttek mortalitása először 2011-ben csökkent 5 ezrelék alá, majd kisebb ingadozások után a 2018. évi 3,4 ezrelék az eddig mért legalacsonyabb értéket jelentette. Az Eurostat adatai szerint a 2018. évi magyarországi csecsemóhalálozási szint megfelelt az Európai Unió átlagának (3,4 ezrelék) [10]. 2019-ben megtört a 2014 óta tartó folyamatos csökkenés, és az 1000 élve születésre jutó l éven aluli meghaltak aránya 3,8 ezrelékre nótt. Az elóző évhez viszonyítva ez jelentős, 11\%-os emelkedést jelent [11].

\section{Célkitüzés}

A jelen vizsgálat célja annak megállapítása, hogy a csecsemőhalálozás aktuális emelkedése statisztikailag szignifikáns-e, vagy a kis értékekből adódó ingadozás következ- ménye, továbbá hogy a kedvezőtlen változás mögött kimutatható-e összefüggés a meghalt csecsemó korával, a halál okával, valamint a halál bekövetkezésének helyszínével (esethelyével).

\section{Adatok és módszerek}

Az élve születési és csecsemőhalálozási adatokat a Központi Statisztikai Hivatal (KSH) bocsátotta rendelkezésünkre. A csecsemőhalandóság 2000 és 2019 közötti trendjét elemeztük, a trendgörbe modellezésére másodfokú polinomot alkalmaztunk. A kedvezőtlen változás lehetséges okainak feltárásához először a 2018. és 2019. évi adatokat hasonlítottuk össze, a statisztikai elemzéshez a khi-négyzet-próbát használtuk. Az élve születések száma 2018-ról 2019-re mindössze 0,7\%-kal csökkent, ezért ezt a változást figyelmen kívül lehet hagyni, így az abszolút esetszámok kerültek bemutatásra. Az elhunyt csecsemőket koruk szerint 0-6 napos, 7-27 napos, 28364 napos korcsoportra osztottuk. A halál helye szerint megkülönböztettünk gyógyintézeti és nem gyógyintézeti eseteket. A halálokok felosztása a BNO 10. revíziója szerinti föcsoportok alapján történt.

Kutatva a nem gyógyintézeti csecsemőhalálozás okait a meghalt csecsemó korcsoportja és a halálozás helye szerint, összevetettük a KSH adatait a Nemzeti Egészségbiztosítási Adatkezelő (NEAK) finanszírozási adataival. A NEAK adatbázisából azon eseteket válogattuk le, amelyeknél a beteg további sorsa 'meghalt' kódot kapott, és életkora (a távozási dátum és a születési dátum különbsége) kevesebb volt, mint 364 nap. Az így kapott adatbázisba bekerültek a halvaszülöttek adatai is, amelyeket a finanszírozó a homogén betegségcsoportok kódolási és besorolási szabályai szerint azonosított, vagyis azokban az esetekben, amikor a felvétel és a távozás időpontja óra-perc pontossággal megegyezett.

Ezt követően a korspecifikus csecsemőhalandóság, a nem gyógyintézeti csecsemőhalálozás, valamint a hirtelen csecsemóhalál szindróma (SIDS) miatt bekövetkezett halálozási arányszám trendjét hosszabb időperiódust figyelembe véve, a 2010 és 2019 közötti időszakra vo- 


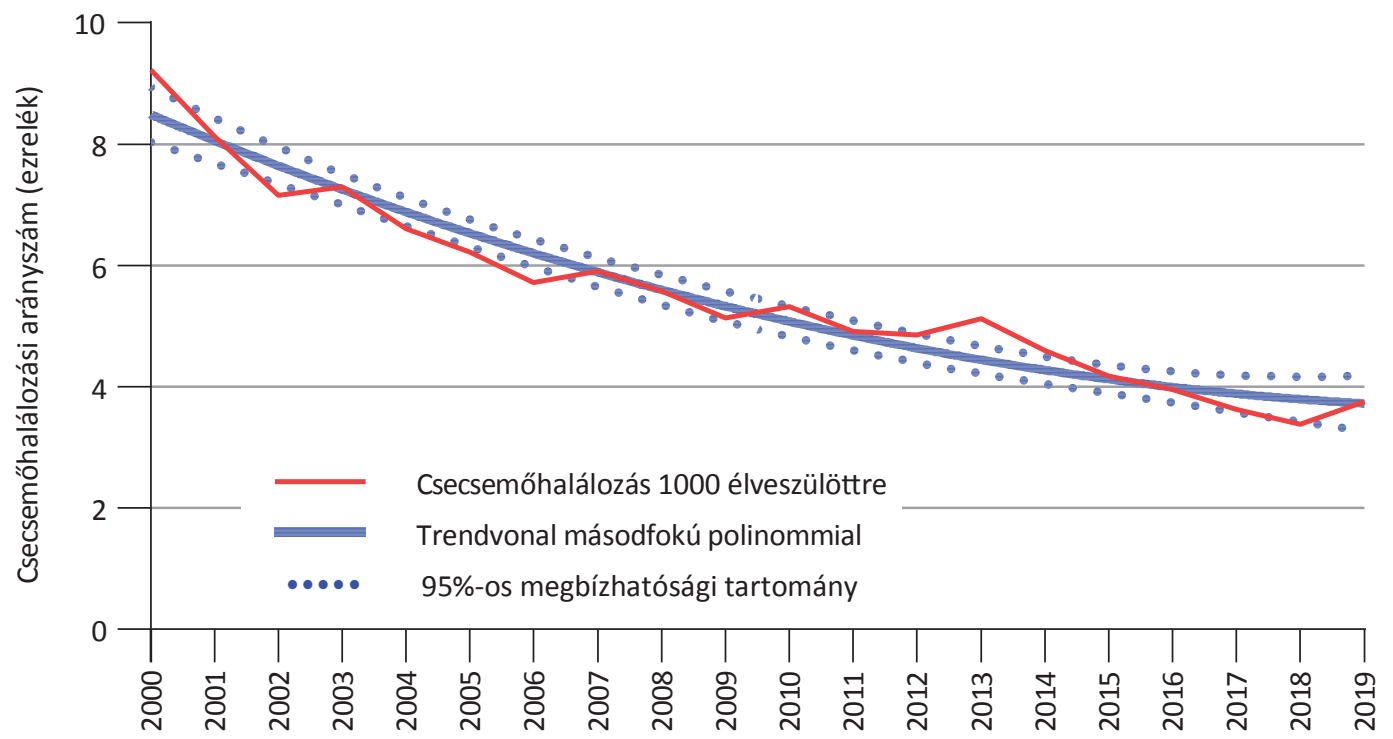

1. ábra | A csecsemőhalálozási arányszám alakulása Magyarországon, 2000-2019

natkozóan vizsgáltuk. A nem gyógyintézeti halálesetek területi különbségeinek kimutatására 10 év összevont adatát járásonként térképesen ábrázoltuk. Az elemzéshez és az ábrázoláshoz az Excel, GraphPad Prism és QGIS programokat használtuk.

\section{Eredmények}

2018-ban 304, 2019-ben 335 csecsemőhalál-eset fordult elő Magyarországon. Mindez a csecsemőhalál-esetek számának 31 fóvel való emelkedését jelentette. Az élve születettek száma 614 fővel csökkent ezen időszakban (2018: 89807 élve születés, 2019: 89193 élve születés). Mindkét összetevő kedvezőtlen változása az élve születések számára vonatkoztatott csecsemőhalálozási arányszám 2018. évi értékének 3,4 ezrelékról 2019-ben a 3,8 ezrelékre való emelkedését okozta. Az utóbbi 20 év jelentős javulásának köszönhetően azonban a 2019. évi érték a 2000-ben mért (9,2 ezrelék) csecsemőhalandósághoz képest $60 \%$-os csökkentést, a 2010. évi 5,3 ezrelékhez képest 30\%-os csökkenést jelentett. Bár a 2019. évi csecsemőhalálozási arányszám magasabb az előző évhez képest, az előző évtizedek trendjére illesztett görbe alapján megfelelt a várható értéknek (1. ábra).

A 2018. és 2019. évi csecsemőhalálozás korcsoportonkénti összehasonlítása során azt tapasztaltuk, hogy 2019-ben a 0-6 napos csecsemók halálozása (korai újszülöttkori halálozás) csökkent a 2018. évihez képest (2018: 150 haláleset, 2019: 128 haláleset), a 7-27 napos csecsemők halálozása (késői újszülöttkori halálozás) növekedett (2018: 50 haláleset, 2019: 74 haláleset). Összevonva a két kategóriát, a 0-27 napos újszülöttkori, vagy más néven korai csecsemőkori halálozás lényegében nem változott (2018: 200 haláleset, 2019: 202 haláleset). Ezzel szemben a késői csecsemőhalál-esetek száma (28364 nap) számottevően növekedett (2018: 104 halál- eset, 2019: 133 haláleset). A két vizsgált évben szignifikánsan különbözött a meghalt csecsemők kormegoszlása $(\mathrm{p}=0,03) .2010$ óta a $0-6$ napos újszülöttek halandósága csökkent a legnagyobb mértékben, a késői újszülöttkori halálozás (7-27 napos) arányszámértéke lényegében nem változott. A 28-364 napos csecsemók halandósága kisebb mértékü javulást mutatott az elmúlt évtizedben (2. ábra).

A halálozás helye szempontjából vizsgálva az adatokat azt kapjuk, hogy gyógyintézetben 2018-ban 265, 2019ben 273 csecsemőhalál fordult elő, ami 8 fónyi különbséggel 3\%-os növekedésnek felelt meg. A nem gyógyintézeti csecsemőhalál-esetek száma 2018-ban 39, 2019 -ben 62 volt. Ez a 23 fónyi többlet 59\%-os növekedést jelentett, amely statisztikailag szignifikánsnak bizonyult ( $\mathrm{p}=0,049)$. Az összes csecsemőhalálozás növekedésében (31 fó) az egyes esethelyi csoportok súlyának vizsgálata azt mutatta, hogy a 2018. évhez képest a 2019. évben tapasztalt növekedésben 26\%-ban ( 8 fó) a gyógyintézeti, 74\%-ban (23 fó) a nem gyógyintézeti esetek szerepeltek. A nem gyógyintézeti halálozás döntő többsége a késői csecsemőkorban következett be (2018:

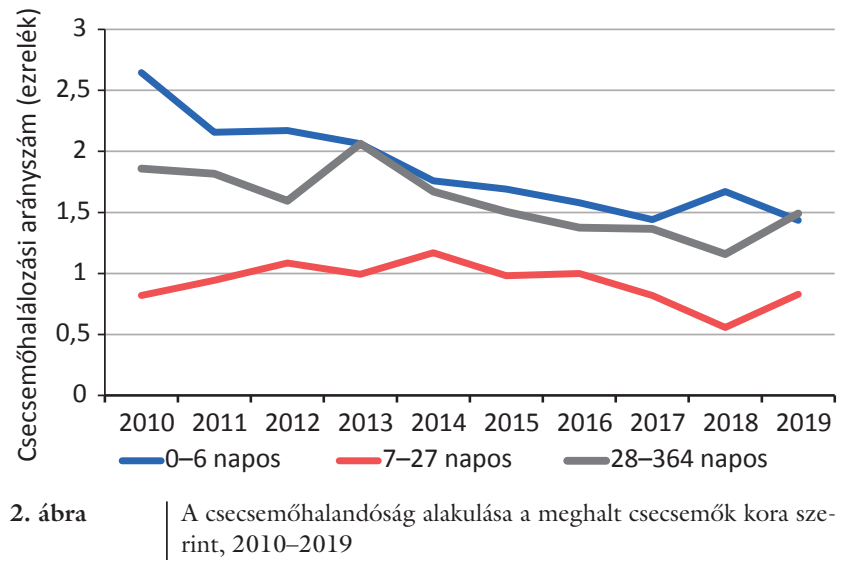


1. táblázat A csecsemőhalálozások száma a halál helye és korcsoport szerint, 2018-2019

\begin{tabular}{l|ccc|ccc}
\hline \multirow{2}{*}{$\begin{array}{l}\text { Korcsoport } \\
\text { nap) }\end{array}$} & \multicolumn{3}{|c|}{2018} & \multicolumn{3}{c}{2019} \\
\cline { 2 - 7 } & \multicolumn{3}{|c|}{ A halálozás helye } & \multicolumn{3}{c}{ A halálozás helye } \\
\cline { 2 - 7 } & $\begin{array}{l}\text { Gyógy- } \\
\text { intézet }\end{array}$ & $\begin{array}{c}\text { Nem } \\
\text { gyógy- } \\
\text { intézet }\end{array}$ & $\begin{array}{c}\text { Össze- } \\
\text { sen }\end{array}$ & $\begin{array}{c}\text { Gyógy- } \\
\text { intézet }\end{array}$ & $\begin{array}{c}\text { Nem } \\
\text { gyógy- } \\
\text { intézet }\end{array}$ & $\begin{array}{c}\text { Össze- } \\
\text { sen }\end{array}$ \\
\hline $0-6$ & 147 & 3 & 150 & 122 & 6 & 128 \\
$7-27$ & 45 & 5 & 50 & 70 & 4 & 74 \\
$28-364$ & 73 & 31 & 104 & 81 & 52 & 133 \\
\hline Összesen & 265 & 39 & 304 & 273 & 62 & 335 \\
\hline
\end{tabular}

2. táblázat |A csecsemőhalottak számának összehasonlítása a KSH- és a NEAK-adatok alapján, 2018-2019

\begin{tabular}{l|l|rc|rc}
\hline \multirow{2}{*}{$\begin{array}{l}\text { Korcsoport } \\
\text { (nap) }\end{array}$} & \multirow{2}{*}{ A halálozás helye } & \multicolumn{2}{|c|}{2018} & \multicolumn{2}{c}{2019} \\
\cline { 3 - 7 } & & KSH & NEAK & KSH & NEAK \\
\hline \multirow{2}{*}{ Halvaszülött } & - & 383 & 240 & 435 & 246 \\
\hline $0-6$ & Gyógyintézeti & 147 & 279 & 120 & 273 \\
& Nem gyógyintézeti & 3 & & 6 & \\
\hline $7-27$ & Gyógyintézeti & 45 & 48 & 70 & 76 \\
& Nem gyógyintézeti & 5 & & 4 & \\
\hline \multirow{2}{*}{$28-364$} & Gyógyintézeti & 73 & 71 & 83 & 86 \\
& Nem gyógyintézeti & 31 & & 52 & \\
\hline
\end{tabular}

KSH = Központi Statisztikai Hivatal; NEAK = Nemzeti Egészségbiztosítási Adatkezelő

79,5\%; 2019: 83,9\%). A korai csecsemőkorban nem gyógyintézetben történó halálozások száma 2-vel, a 28364 napos korban történő halálozások száma 21 fövel (68\%) emelkedett 2019-ben az elóző évhez képest (nem szignifikáns változás, $\mathrm{p}=0,58)$ (1. táblázat).
A csecsemőhalálozási adatok kutatása során a KSH- és a NEAK-adatforrások összehasonlításakor azt találtuk, hogy a 0-6 napos korban meghalt újszülöttek vonatkozásában a NEAK-állományban jóval több, „formailag” csecsemőhalálként azonosítható eset lelhető fel, mint a KSH-állományban. Ennek oka, hogy a NEAK-jelentésekben a halva születés és a korai újszülöttkori halálozás nem különíthetố el megbízhatóan a kódolási hibák miatt. A 7-27 napos, illetve a 28-364 napos halálozás esetén fordított jelenség figyelhetô meg: a NEAK-adatok kevesebb csecsemőhalál-esetet mutattak, mint amennyit a KSH-adatok jeleztek. Feltételezve azt, hogy a gyógyintézeti csecsemőhalál-eseteknél szükségszerúen keletkezik jelentés a NEAK felé, a KSH-nál mutatkozó többletesetek vonatkozásában azt kell gondolnunk, hogy ezek nem egészségügyi intézményben bekövetkezett események. Valóban, a 28-364 napos korosztályban mutatkozó NEAK- és KSH-adatok különbsége megközelítőleg azonos a nem gyógyintézeti csecsemőhalál-esetszámokkal (2. táblázat).

Annak eldöntésére, hogy a nem gyógyintézeti csecsemőhalálozás 2019. évi emelkedése valós, tendenciózus kedvezőtlen változásra utal-e, 10 évre visszamenőleg megvizsgáltuk a csecsemőhalálozások esethelyi számát és megoszlását. A vizsgálat során azt találtuk, hogy a nem gyógyintézeti csecsemőhalál-esetek száma és részaránya évról évre viszonylag nagy variabilitást mutatott. Miközben a csecsemőhalandóság nagymértékben csökkent 10 esztendő alatt, a nem intézményben bekövetkezett esetek aránya inkább növekedett. 2019-ben kiugróan magas volt a nem gyógyintézetben elhunyt csecsemők száma (62 fó) és részaránya (19\%) a csecsemóhalálozáson belül (3. ábra).

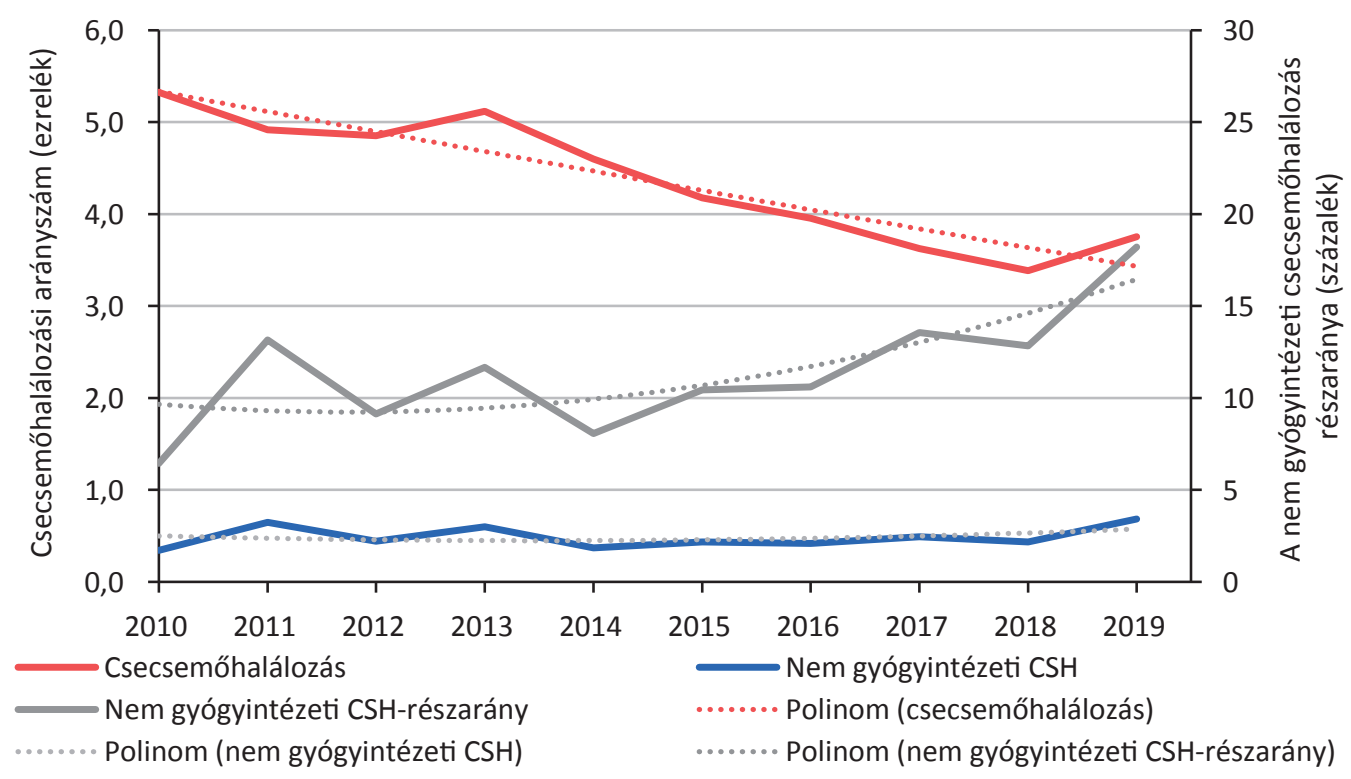

\begin{tabular}{l|l} 
3. ábra & $\begin{array}{l}\text { A csecsemőhalandóság és a nem gyógyintézeti halálozás arányának alakulása, 2010-2019 } \\
\mathrm{CSH}=\text { csecsemőhalálozás }\end{array}$
\end{tabular} 
Felismerve a nem gyógyintézeti esetek növekvő súlyát a csecsemőhalálozásban, részletesen vizsgáltuk, hogy milyen területi különbségek adódtak ebben a mutatóban. Egy kisebb településen a nem gyógyintézeti csecsemóhalálozás természetesen extrém ritka esemény, ezért 10 év összevont adatait járásonként vettük figyelembe. Ennek alapján a legtöbb nem gyógyintézeti halálesetet a Miskolci (14 eset), a Debreceni (13 eset), a Szolnoki (12 eset) és a Salgótarjáni járásban (11 eset) regisztrálták. További 12 járásban 5-nél több eset fordult elő a vizsgált időszakban. Ugyanakkor a 174 járás és 23 fóvárosi kerület közül 49-ben egyetlen nem gyógyintézeti csecsemőhalál-eset sem következett be a vizsgált 10 év során (4. ábra). Az egyes járások népesség- és élveszületési számai természetesen nagymértékben különböznek, így az abszolút számok ismerete mellett az 1000 élve születésre jutó nem gyógyintézeti csecsemőhalottak száma informatívabb. A 10 évre összevont nem gyógyintézeti csecsemőhalálozási arányszám országos átlagértéke 0,49 ezrelék volt. $\mathrm{Az}$ országos átlag több mint négyszeresét meghaladó érték mutatkozott 6 járásban: a Szécsényi (2,76 ezrelék), a Karcagi (2,19 ezrelék), a Bátonyterenyei (2,19 ezrelék), a Szerencsi (2,08 ezrelék), a Jászapáti $(2,01$ ezrelék) és a Putnoki (2,01 ezrelék) járásban (5. ábra).

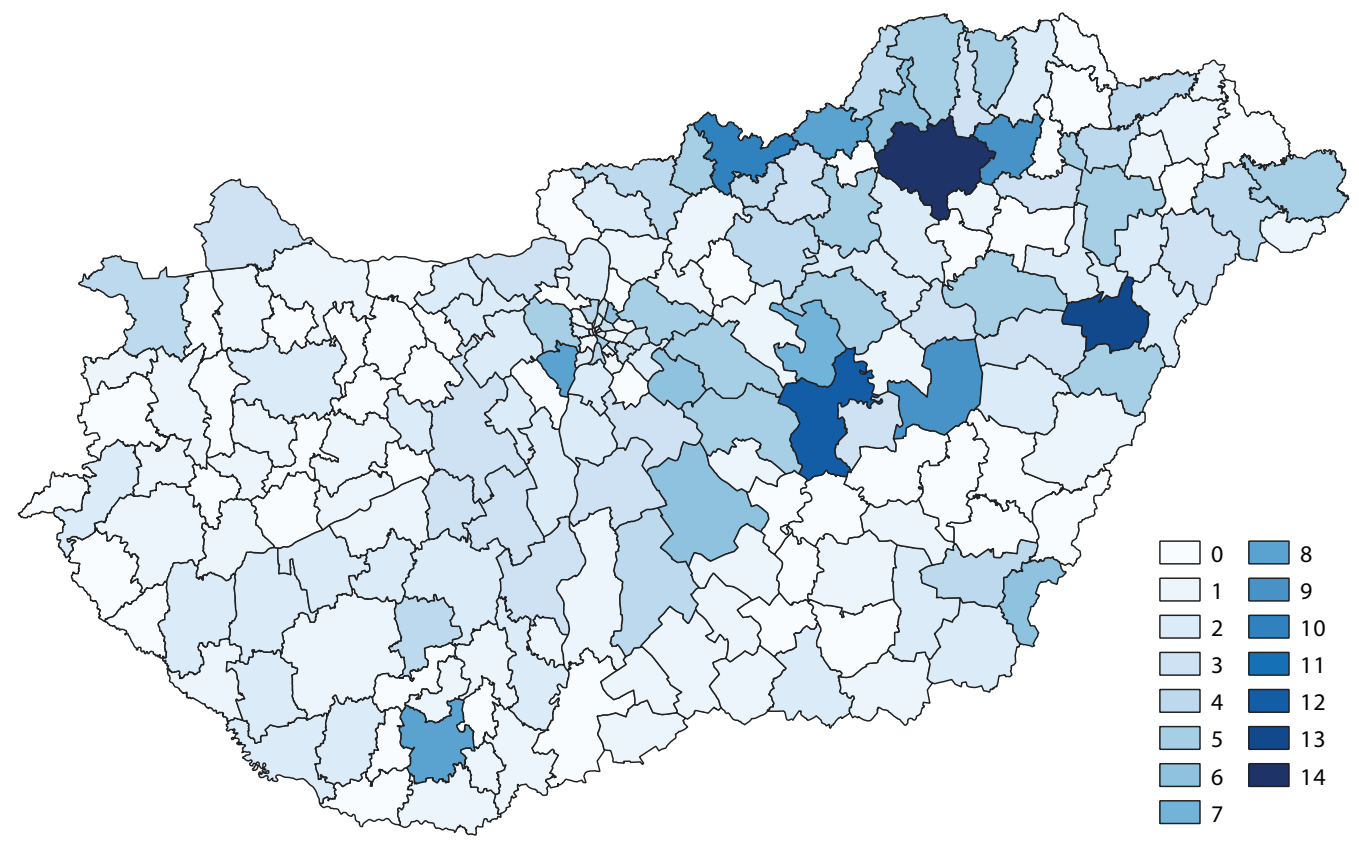

4. ábra

| A nem gyógyintézeti csecsemőhalálozások száma járások szerint, 2010-2019

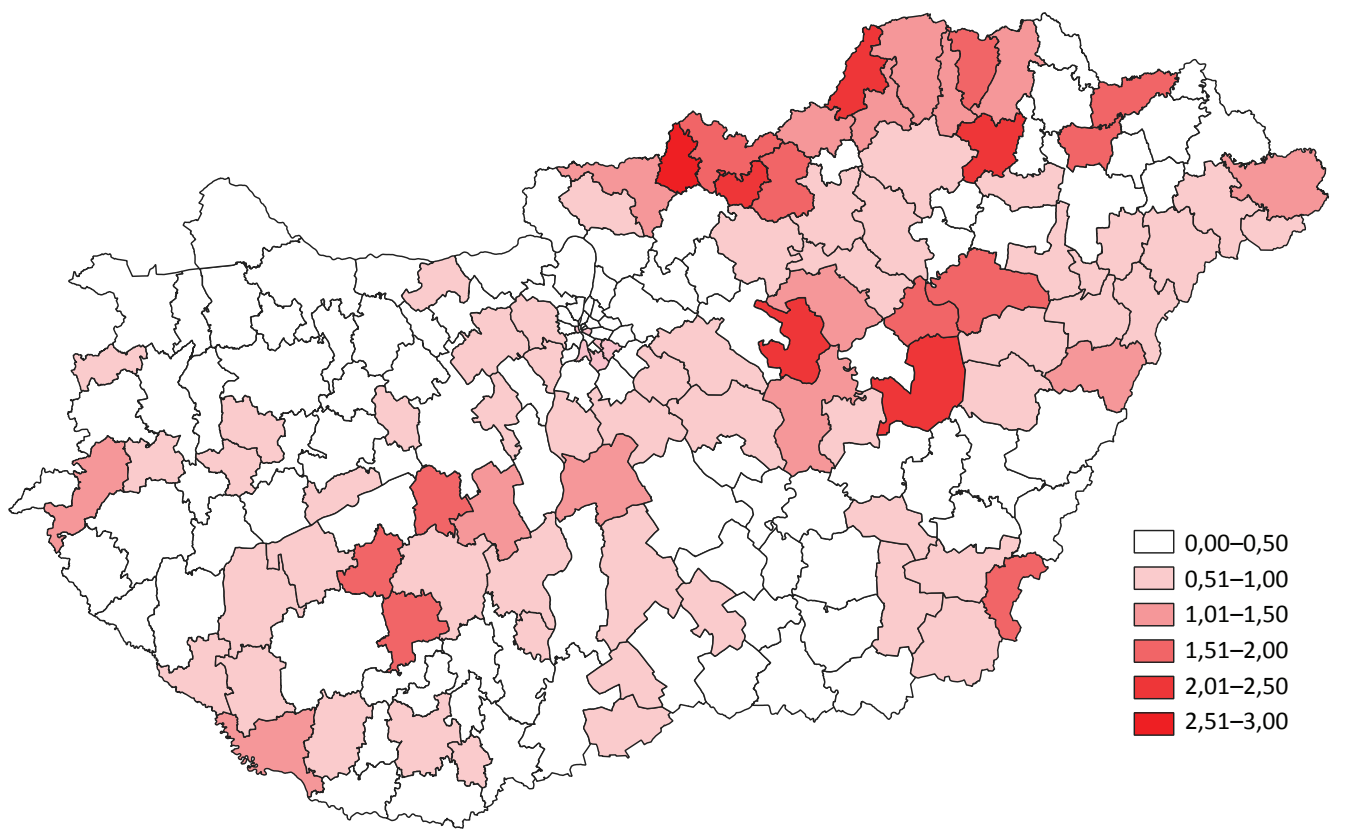

5. ábra | A nem gyógyintézeti csecsemóhalálozások száma 1000 élve születésre vonatkoztatva járások szerint, 2010-2019 
3. táblázat |A csecsemóhalálozások száma a halál helye és a halálok szerint, 2018-2019

\begin{tabular}{|c|c|c|c|c|c|c|}
\hline \multirow[t]{3}{*}{ Halálok } & \multicolumn{3}{|c|}{2018} & \multicolumn{3}{|c|}{2019} \\
\hline & \multicolumn{3}{|c|}{ A halálozás helye } & \multicolumn{3}{|c|}{ A halálozás helye } \\
\hline & Gyógyintézet & $\begin{array}{l}\text { Nem } \\
\text { gyógyintéze }\end{array}$ & Összesen & Gyógyintézet & $\begin{array}{l}\text { Nem } \\
\text { gyógyintézet }\end{array}$ & Összesen \\
\hline I. Fertőző és élősdiek okozta betegségek & 4 & - & 4 & 6 & 1 & 7 \\
\hline II. Daganatok & 1 & - & 1 & 4 & 1 & 5 \\
\hline $\begin{array}{l}\text { III. A vér és a vérképző szervek betegségei és az } \\
\text { immunrendszert érintő bizonyos rendellenességek }\end{array}$ & 1 & - & 1 & 1 & - & 1 \\
\hline IV. Endokrin, táplálkozási és anyagcsere-betegségek & 3 & - & 3 & 1 & - & 1 \\
\hline VI. Az idegrendszer betegségei & 4 & - & 4 & 3 & 1 & 4 \\
\hline IX. A keringési rendszer betegségei & 4 & - & 4 & 1 & 1 & 2 \\
\hline X. A légzőrendszer betegségei & 2 & 4 & 6 & - & 5 & 5 \\
\hline XII. A bőr és a bőr alatti szövet betegségei & - & - & - & 1 & - & 1 \\
\hline $\begin{array}{l}\text { XVI. A perinatalis szakban keletkező bizonyos } \\
\text { állapotok }\end{array}$ & 150 & 9 & 159 & 176 & 15 & 191 \\
\hline XVII. Veleszületett rendellenességek & 91 & 2 & 93 & 73 & 8 & 81 \\
\hline $\begin{array}{l}\text { XVIII. Máshová nem osztályozott panaszok } \\
\text { (hirtelen csecsemóhalál szindróma) }\end{array}$ & $3(3)$ & $17(15)$ & $20(18)$ & $5(5)$ & $24(24)$ & $29(29)$ \\
\hline XX. A morbiditás és mortalitás külső okai & 2 & 7 & 9 & 2 & 6 & 8 \\
\hline Összesen & 265 & 39 & 304 & 273 & 62 & 335 \\
\hline
\end{tabular}

2019-ben az előző évhez képest növekedett a perinatalis szakban keletkező bizonyos állapotok (32 fó) és a máshová nem osztályozott állapotok ( 9 fö) miatti csecsemőhalálozás, míg a veleszületett rendellenességek miatti halálozás csökkent (12 fö). A 2018. és 2019. évi halálokok megoszlásában nem találtunk szignifikáns különbséget. Külön megvizsgálva a nem gyógyintézeti halálozás okait azt találtuk, hogy a perinatalis betegségekben
(6 fơvel), a fejlődési rendellenességekben (6 fơvel) és a SIDS miatt (9 fővel) több csecsemő halt meg 2019-ben, mint 2018-ban. A külső ok hatására történő csecsemóhalálozások száma viszont kisebb volt (1 fôvel) (3. táblázat).

A SIDS 2019. évi emelkedése miatt külön megvizsgáltuk ennek a haláloknak az 1000 élveszülöttre viszonyított arányszámát az elmúlt 10 évben. 2010 és 2018 kö-

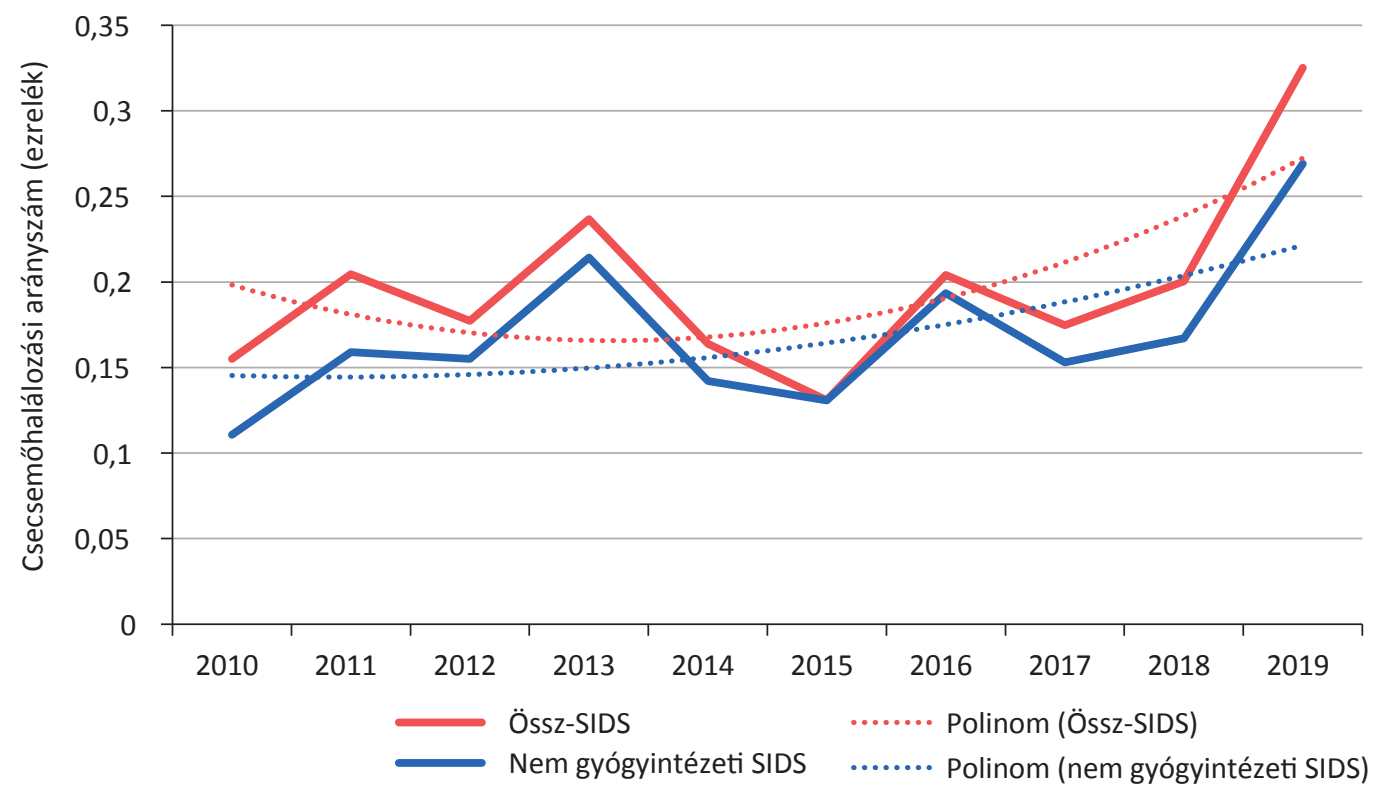

6. ábra A hirtelen csecsemőhalálozás arányszámának alakulása, 2010-2019
SIDS = hirtelen csecsemőhalál szindróma 
zött a hirtelen csecsemőhalálozás arányszáma 0,11 és 0,21 ezrelék között ingadozott, a 2019. évben azonban kiugróan magas volt $(0,27$ ezrelék $)$, ami nem illeszkedett az előző évek trendjébe (6. ábra).

\section{Megbeszélés}

2019-ben megtorpanni látszik a hazai csecsemőhalandóság évtizedek óta tartó csökkenő trendje, amelynek során 2000 óta $60 \%$-kal, 2010-hez viszonyítva 30\%-kal csökkent a mutató értéke. A KSH adatai szerint 2019-ben ( 3,8 ezrelék) a hazai csecsemőhalandóság magasabb volt a 2018. évi (3,4 ezrelék) és a 2017. évi (3,6 ezrelék) adatoknál. A statisztikai elemzés eredménye szerint a 2019-es érték megfelel az előző évek adatai alapján várható értéknek, vagyis 95\%-os biztonsággal kijelenthető, hogy a 2019. évi magasabb érték természetes (véletlen) ingadozás következménye. Ennek ellenére az előző évihez képest magasabb abszolút számok indokolttá tették a csecsemőhalálozás összetevőinek vizsgálatát, esetleges új kedvezőtlen belső trendek feltárása végett.

A csecsemőhalálozás részletesebb elemzése során megállapítottuk, hogy 2019-ben az előző évi adatokhoz képest a korai újszülöttkori időszak (0-6 nap) csecsemőhalálozása csökkent, a késői neonatalis időszaké (7-27 nap) növekedett, aminek nyomán a teljes újszülöttkori halálozás (0-27 nap) lényegében nem változott. Mindez megfelel annak a trendnek, amely elsősorban a 2010-es évek elején mutatkozott, amikor a korai 0-6 napos halálozás a későbbi időszakra (7-27 nap) tolódott. Mindez a leginkább a perinatológiai szakmai tevékenység (várandósgondozás, szülészet és neonatológia) eredményességét tükrözi. Ugyanakkor a 28-364 nap közötti, késői csecsemőhalálozás kifejezetten emelkedett 2019-ben, és ez okozta a 2019. évi magasabb csecsemőhalálozási arányt. A csecsemőhalálozás esethely szerinti vizsgálata során azt láttuk, hogy a nem gyógyintézetben történő halálesetek részarányát növekvő trend jellemezte 2010 és 2019 között, az utolsó évben pedig kiugróan, 59\%-kal emelkedett a számuk. A 2019. évi csecsemőhalálozás növekedéséért 74\%-ban a nem gyógyintézeti esetek voltak felelősek. A nem gyógyintézeti halálozás döntő többsége a késői csecsemőkorban következett be.

A csecsemőhalálozás emelkedését okozó, nem intézeti esetekre vonatkozó további egészségügyi adat után kutatva, a KSH- és NEAK-adatok különbségéből arra a következtetésre jutottunk, hogy a NEAK felé nem történt jelentés ezen esetekről. A védőnői szakmai irányítás, továbbá az igazságügyi orvostani intézet tájékoztatása szerint ezen szervezetek sem vezetnek nyilvántartást a nem gyógyintézetben meghalt csecsemőhalál-esetekről.

A nem gyógyintézeti csecsemóhalálozás területi megoszlásának vizsgálata során figyelembe vettük, hogy az egyes megyékre jutó, várhatóan nagyon alacsony éves esetszám miatt nagy szerepet kaphat egy-egy váratlan esemény, baleset, maga az esetlegesség [7]. Ezért a viszonylag kicsiny esetszámok miatt 10 évet felölelő idő- szakot tanulmányoztunk. A 174 járás és 23 fóvárosi kerület közül 49 helyen egyáltalán nem fordult elő ilyen eset, ugyanakkor 15 járásban és egy kerületben 5-nél több esetet regisztráltak 10 év leforgása alatt. Egyes járásokban ötször gyakoribb volt a nem gyógyintézeti csecsemőhalálozások aránya 1000 élve születésre vetítve az országos átlagnál. Általánosságban a csecsemőhalandóság területi különbségeiben meghatározóak a szociális, gazdasági eltérések, bizonyított az összefüggése az anyai iskolázottsággal, az egy személyre jutó jövedelemmel $[12,13]$. Napjainkban a késői csecsemőhalálozást inkább a gazdasági-társadalmi különbségek és kevésbé az egészségügyi ellátórendszer befolyásolja [14, 15]. Vélekedésünk szerint a nem gyógyintézeti csecsemőhalandóság aktuális hazai növekedésében és a járások között mutatkozó szélsőséges különbségben is inkább a társadalmi és szociokulturális tényezők játszanak meghatározó szerepet [16-18].

A halálokok vizsgálata során azt tapasztaltuk, hogy 2019-ben a „perinatalis szakban keletkező bizonyos állapotok” és a „hirtelen csecsemőhalál szindróma” esetszámok növekedtek 2018-hoz képest. A gazdaságilag fejlett országokhoz hasonlóan, napjainkra a SIDS a csecsemőhalálozás vezető haláloki kategóriái közé emelkedett Magyarországon is [19, 20]. A SIDS előfordulása és az adott terület társadalmi-gazdasági körülményei között szoros összefüggést találtak egyes szerzők [21, 22].

A 2019. évi magyarországi csecsemőhalálozási adatok hosszabb távra visszatekintő összehasonlító vizsgálatával megállapítottuk, hogy a korai neonatalis halálozásban elért kedvező eredmények változatlanok. A késői csecsemóhalálozás növekvő tendenciát mutat, amelyen belül a nem gyógyintézeti halálozás jól azonosítható regionális halmozódással figyelemre méltó módon növekszik. A kedvezőtlen tendencia visszafordítására célzott szakmapolitikai lépések szükségesek [23], amelyek első lépése az egyes esetek pontos megismerése és az okok feltárása. A rendszerváltást megelőzően megyei szinten, regionálisan rendszeresen zajlottak ún. perinatalis, illetve csecsemőhalálozási értekezletek: ezek olyan értékelőkonferenciák voltak, amelyek az egyes esetek alapos és őszinte kiértékelésével sokat segítettek az ismétlődő esetek csökkentésében. A rendszerváltás után a kártérítési esetek gyüjtőhelyéül szolgáltak az ilyen konferenciák az ügyvédek számára. Emiatt megszünt az őszinteség, és a konferenciák elvesztették szerepüket. A csecsemőhalálozási értekezletek újraindításának gondolatát mind az orvosszakmai, mind a gyermekvédelmi szakemberek, mind a politikai szereplők támogatják, amit számos, közelmúltban napvilágot látott dokumentum és irányelv tanúsít [24-26]. Az egyedi esetek csoportos, multidiszciplináris szakmai kiértékelése a jövőben akkor járhat érdemi haszonnal, ha az szigorúan csak az érintett szakmai szereplők bevonásával és az egészségügyi és személyi adatvédelem szem előtt tartásával történik. 


\section{Következtetés}

2019-ben nőtt a csecsemőhalálozás, ami fenyegeti az elmúlt évtizedben tapasztalt kedvező csökkenő csecsemőhalálozási trendet. 2019-ben az újszülöttkori csecsemőhalálozás (0-27 nap) nem változott a megelőző évhez képest. 2019-ben kiugróan magas volt a nem gyógyintézeti késői csecsemőhalál-esetek száma és aránya, ezen esetek tették ki az összes csecsemőhalál 15,5\%-át, és kétharmad részben feleltek a csecsemóhalandóság növekedéséért. Az elmúlt évtizedben a nem gyógyintézeti csecsemőhalálozás feltûnő regionális halmozódást és növekedési tendenciát mutatott.

A növekvő, nem gyógyintézeti csecsemőhalálozás jelensége a továbbiakban szoros monitorozást és az okok további kutatását igényli. Az okok feltárásának fontos eszköze lehetne, ha minden egyes csecsemőhalál-eset értékelése megtörténne a jövőben az összes érintett egészségügyi, szociális és közigazgatási szereplő bevonásával (korábban „csecsemőhalálozási” értekezlet). A kedvezőtlen tendencia megállítása elsősorban az okok megismerésére alapozott, járás-, településszinten megvalósuló, társadalmi csoportokra differenciált megelőző programoktól várható a jövőben.

Anyagi támogatás: A közlemény megírása anyagi támogatásban nem részesült.

Szerzői munkamegosztás: A vizsgálat megtervezése: Sz. M., V. J., V. A., Sz. A. Adatszolgáltatás: Bné G. G. $\mathrm{Az}$ adatok értelmezése és feldolgozása, statisztikai elemzések: V. A., V. J., P. B., Sz. M. Táblázatok, ábrák készítése: E. L., V. A. A kézirat megszövegezése: Sz. M., V. A., P. B., Sz. A. A szerzők a cikk végleges változatát elolvasták és jóváhagyták.

Érdekeltségek: A szerző́knek nincsenek érdekeltségeik.

\section{Köszönetnyilvánítás}

A szerzők köszönetüket fejezik ki Kovács Adriennek a Társadalmi Felzárkózásért Felelős Helyettes Államtitkárság referensének a térképes ábrázolásban nyújtott segítségéért. Hálásak vagyunk az egészségügyi ellátási adatokért a Nemzeti Egészségbiztosítási Alapkezelő vezetőinek és munkatársaiknak.

\section{Irodalom}

[1] Vargáné Hajdú P, Boján F. Demographic and epidemiological methods in public health. [Demográfiai és epidemiológiai módszerek a népegészségügyben.] Literatura Medica Kiadó, Budapest, 1996. [Hungarian]

[2] Hertz E, Hebert JR, Landon J. Social and environmental factors and life expectancy, infant mortality, and maternal mortality rates: results of a cross-national comparison. Soc Sci Med. 1994; 39: 105-114

[3] Valek A. Mortality data. In: Tulassay T. (ed.) Clinical pediatrics. [Halálozási adatok. In: Tulassay T. (szerk.) Klinikai gyermekgyó- gyászat.] Medicina Könyvkiadó, Budapest, 2016; pp. 97-98. [Hungarian]

[4] Reidpath DD, Allotey P. Infant mortality rate as an indicator of population health. J Epidemiol Community Health 2003; 57: 344-346.

[5] Hajdú T, Kertesi G, Kézdi G, et al. The effects of expanding a neonatal intensive care system on infant mortality and long-term health impairments. CERS-IE Working Papers. Institute of World Economics, Centre for Economic and Regional Studies, Budapest, 2020.

[6] Hungarian Central Statistical Office. Infant mortality. [Központi Statisztikai Hivatal. Csecsemőhalálozás.] Statisztikai Tükör 2019. febr. 22. Available from: http://www.ksh.hu/docs/hun/ xftp/stattukor/csecsemohalalozas.pdf [accessed: November 27, 2020]. [Hungarian]

[7] Gárdos É. Infant mortality in space and time. [A csecsemőhalandóság térben és idóben.] KorFa 2002; 3-4: 3-4. [Hungarian]

[8] Onambele L, San Martin-Rodríguez L, Niu H, et al. Infant mortality in the European Union: a time trend analysis of the 19942015 period. [Mortalidad infantil en la Unión Europea: análisis de tendencias en el período 1994-2015.] An Pediatr (Barc). 2019; 91: 219-227. [Spanish]

[9] MacDorman MF, Mathews TJ. Behind international rankings of infant mortality: how the United States compares with Europe. Int J Health Serv. 2010; 40: 577-588.

[10] Eurostat. Infant mortality halved between 1998 and 2018. Eurostat News, 2020. Available from: https://ec.europa.eu/eurostat/web/products-eurostat-news/-/DDN-20200309-1 [accessed: November 27, 2020].

[11] Hungarian Central Statistical Office. Population movement, 2019. [Központi Statisztikai Hivatal. Népmozgalom, 2019.] Statisztikai Tükör 2020. május 12. Available from: http://www. ksh.hu/docs/hun/xftp/idoszaki/nepmozg/nepmozg19/index.html [accessed: November 27 2020]. [Hungarian]

[12] Taylor-Robinson D, Lai ET, Wickham S, et al. Assessing the impact of rising child poverty on the unprecedented rise in infant mortality in England, 2000-2017: time trend analysis. BMJ Open 2019; 9: e029424.

[13] Wang H, Liddell CA, Coates MM, et al. Global, regional, and national levels of neonatal, infant, and under- 5 mortality during 1990-2013: a systematic analysis for the Global Burden of Disease Study 2013. Lancet 2014; 384: 957-979.

[14] Arntzen A, Samuelsen SO, Bakketeig LS, et al. Socioeconomic status and risk of infant death. A population-based study of trends in Norway, 1967-1998. Int J Epidemiol. 2004; 33: 279288.

[15] Luo ZC, Wilkins R, Kramer MS, et al. Effect of neighbourhood income and maternal education on birth outcomes: a population-based study. CMAJ 2006; 174: 1415-1420.

[16] Rosicova K, Madarasova Geckova A, van Dijk JP, et al. Regional socioeconomic indicators and ethnicity as predictors of regional infant mortality rate in Slovakia. Int J Public Health 2011; 56: 523-531.

[17] Moravcsik-Kornyicki Á, Kósa Zs, Gyulai A, et al. Regional inequalities of health status of pregnant women in Hungary. Longterm series analysis. [Területi egyenlőtlenségek hosszú idősoros elemzése a várandós nők egészségi állapotát vizsgálva.] Orv Hetil. 2017; 158: 1131-1142. [Hungarian]

[18] Sárváry A, Kósa Zs, Jávorné RE, et al. Socioeconomic status, health related behaviour, and self-rated health of children living in Roma settlements in Hungary. Cent Eur J Public Health 2019; $27: 24-31$.

[19] de Visme S, Chalumeau M, Levieux K, et al. National variations in recent trends of sudden unexpected infant death rate in Western Europe. J Pediatr. 2020; 226: 179-185.e4. 
[20] Erck Lambert AB, Parks SE, Shapiro-Mendoza CK. National and state trends in sudden unexpected infant death: 1990-2015. Pediatrics 2018; 141: e20173519.

[21] Wood AM, Pasupathy D, Pell JP, et al. Trends in socioeconomic inequalities in risk of sudden infant death syndrome, other causes of infant mortality, and stillbirth in Scotland: population based study. BMJ 2012; 344: el552.

[22] Müller-Nordhorn J, Schneider A, Grittner U, et al. International time trends in sudden unexpected infant death, 1969-2012. BMC Pediatr. 2020; 20: 377

[23] Robinson T, Brown H, Norman PD, et al. The impact of New Labour's English health inequalities strategy on geographical inequalities in infant mortality: a time-trend analysis. J Epidemiol Community Health 2019; 73: 564-568.

[24] Csordás Á. The profession of health visitor 2010. Our profession is marked as Hungaricum today. [Védőnői hivatás 2010. A hungarikumként jelzett hivatásunk napjainkban.] Védőnő 2011; 21(1): 28-39. [Hungarian]

[25] The Secretary of State for Health Care of the Hungarian Ministry of National Resources. Guidelines on the responsibilities of health care providers in case of suspicion of child abuse or ne- glect. [Egészségügyi szakmai irányelv. Az egészségügyi ellátók feladatairól gyermekek bántalmazásának, elhanyagolásának gyanúja esetén.] Emberi Erőforrások Minisztériuma, Egészségügyért Felelős Államtitkárság, Budapest, 2020. Available from: https://kollegium.aeek.hu/Iranyelvek/Index [accessed: January 8,2021 ]. [Hungarian]

[26] The Secretary of State for Health Care of the Hungarian Ministry of National Resources. Revived healthcare, recovering Hungary - Semmelweis Plan to save healthcare. [Újjáélesztett egészségügy, gyógyuló Magyarország - Semmelweis Terv az egészségügy megmentésére.] Nemzeti Erőforrás Minisztérium, Egészségügyért Felelős Államtitkárság, Budapest, 2011. Available from: https://2010-2014.kormany.hu/download/3/c4/ $40000 /$ Semmelweis\%20Terv\%20szakmai\%20koncepci\%C3\%B3\%202011.\%20j\%C3\%BAnius\%2027.pdf [accessed: January 8,2021 ]. [Hungarian]

(Valek Andrea dr., Budapest, Bókay u. 53., 1083 e-mail: valek.andrea@med.semmelweis-univ.hu)

"Secundus est a matre nutricis dolor." (A dajka fájdalma mindjárt az anyáé után következik.)

A cikk a Creative Commons Attribution 4.0 International License (https://creativecommons.org/licenses/by/4.0/) feltételei szerint publikált Open Access közlemény, melynek szellemében a cikk bármilyen médiumban szabadon felhasználható, megosztható és újraközölhető, feltéve, hogy az eredeti szerző és a közlés helye, illetve a CC License linkje és az esetlegesen végrehajtott módosítások feltüntetésre kerülnek. (SID_1) 